\title{
An assessment of the moderating role of employees' cultural orientations amongst foreign manufacturing multinational companies in Kenya
}

\begin{abstract}
Authors:
Beatrice A. Dimba ${ }^{1}$

Robert Rugimbana²

Affiliations:

${ }^{1}$ Faculty of Management and Commerce, Strathmore

University, Kenya
\end{abstract}

${ }^{2}$ Faculty of Economics and Finance, Tshwane University of Technology, South Africa

Correspondence to:

Robert Rugimbana

Email:

rugimbanar@tut.ac.za

Postal address:

Private Bag X680, Pretoria,

South Africa

Dates:

Received: 10 Jan. 2012

Accepted: 24 Apr. 2013

Published: 11 Sept. 2013

How to cite this article: Dimba, B.A., \& Rugimbana, R. (2013). An assessment of the moderating role of employees' cultural orientations amongst foreign manufacturing multinationa companies in Kenya. SA Journal of Human Resource Management/SA Tydskrif vir Menslikehulpbronbestuur, 11(1), Art. \#453, 11 pages. http://dx.doi.org/10.4102/ sajhrm.v11i1.453

\section{Copyright:}

(C) 2013. The Authors. Licensee: AOSIS

OpenJournals. This work is licensed under the Creative Commons Attribution License.

Read online:
Orientation: This article investigates the question, of whether culture really matters in implementing international strategic human resource management (SHRM) practices.

Research purpose: Specifically, this study sought to investigate the extent to which employee cultural orientations moderate the link between SHRM practices and firm performance in large foreign manufacturing multinational companies in Kenya.

Motivation for the study: Large foreign multinational companies have generally applied SHRM practices without adaptation when trying to improve employee performance even though resource based perspectives argue for the consideration of employees' cultural orientations.

Research design, approach and method: SHRM practices were conceptualised as independent variables measured through distinct practices. Organisational performance as a dependent variable was measured using constructs of image, interpersonal relations, and product quality. Cultural dimensions adopted for this study were power distance, uncertainty avoidance, individualism or collectivism, and masculinity or femininity. The above conceptual framework was tested by the use of both quantitative and qualitative techniques with data from fifty (50) large foreign multinational companies operating in Kenya.

Main findings: Findings indicated that the relationship between SHRM practices and firm performance depend to a greater extent on employee cultural orientations when power distance is considered. Power distance (PD) refers to the extent ofpeople accepting that power in institutions and organisations when distributed unequally. The greater the PD, the greater the acceptance of this inequality.

Practical/managerial implications: The study supported the notion that the relationship between SHRM practices and firm performance is moderated by power distance through motivation but not by the other three bipolar dimensions namely, Uncertainty Avoidance, Masculinity or Femininity and Individualism or Collectivism.

Contribution/value-add: This is the first large-scale empirical article that has focused on the moderating role of employees' cultural orientations in large foreign manufacturing companies operating in Kenya.

\section{Introduction}

Over the last ten years or so, significant differences of opinion have emerged around two related issues. How to adequately implement strategic human resources strategies to improve firm performance and, whether or not a 'bundle of HR best practices' exists that can be applied in all contexts with predictable outcomes. In regards to the first issue, the question of whether a direct link between strategic human resources management (SHRM) practices and firm performance exists, the arguments are equivocal. Some studies have demonstrated the existence of direct links between SHRM practices and firm performance (Edwards \& Wright, 2001). Other studies (Dimba, 2010; Katou \& Budhwar, 2006) have shown that SHRM practices do not lead directly to business performance but rather they influence employee motivation. In other words, it is employee outcomes that ultimately influence performance.

With regards to the second issue (named above), two perspectives exist. On the one hand researchers, who embrace the Universalist perspective, emphasise the notion of a 'bundle of best practices' in relation to human resources (HR) practices. However, on the other hand, there is an opposing viewpoint which disapproves of the notion of a best practices bundle. Specifically, Gerhart $(2005$, p. 178) argues that an important concern revolves around the fact that '... it seems unlikely that one set of SHRM practices will work equally well no matter the context'. This is particularly significant given that contextual variables, chiefly national culture or employee 
cultural orientations have been found in various studies to have an influence on the choice of HRM strategies (Aycan, Al-Hamadi, Davis \& Budhwar, 2007; Nyambegera, Daniels \& Sparrow, 2001).

Mamman and Adeoye (2007) argue that as developing countries are increasingly adopting technologies and expertise that are similar to those of developed countries, foreign multinational companies (MNCs) tend to become conduits for transferring host-country SHRM practices to their developing host-countries often without making any adaptive changes to these practices. The underlying belief in these practices is that SHRM practices in developing countries are seen as converging towards those of developed countries. This belief is not widely accepted, particularly not amongst the growing number of writers who have shown that cultural diversity in societies around the globe tend to retard and even reverse convergence (Horwitz et al., 2006). On the basis of the foregoing arguments, there is a need for additional robust and quantitative evidence to support the MNCs' SHRM-performance link and investigations from different contexts. Thus, the aim of this study is to investigate the question of what is the likely cultural influence on the choice of SHRM practices amongst foreign multinationals in Kenya. Specifically, the research objectives of the study will try to determine:

- The relationship between Human Resources practices and performance,

- The relationship between culture and SHRM practices,

- Whether cultural orientation moderates SHRM practices and employee motivation and

- Whether employee motivation mediates between SHRM and firm performance.

\section{Literature review}

Given that SHRM practices are not standardised, some scholars (Katou \& Budhwar, 2007) have proposed the use of a mediating model that adopts two systems of SHRM practices that are usually present in almost all works, namely, resourcing and development, aiming at attracting and developing human resources, and rewards and relations which aim at retaining and motivating human resources. Specifically this study applies motivation as a mechanism by which SHRM practices impact upon organisational performance (Gerhart, 2005).

Studies (Ryan \& Deci, 2000) show that motivation, being a translation of effort and strength of behavior, leads to performance. However, specifications of individual and situational attributes are required. People can be motivated because they value an activity or because there is a strong external influence. The issue of people supporting a certain behavior out of their interests and values, or demonstrating it for reasons external to the self, is common across every culture. Most studies examining the relationship between SHRM practices and organisational performance have been conducted on large manufacturing companies in a few developed countries (the US and the UK); but the question still left unanswered is the influence of SHRM practices on human capital or specifically, employee motivation, and organisational performance in varied cultural contexts (Katou \& Budhwar, 2007).

Viewed from a different perspective, the majority of work in SHRM generally adopts the resource-based view (RBV) theory that focuses on the firm's internal resources (Katou \& Budhwar, 2007). The workplace stresses the role played by employees in enhancing a firm's competitive capabilities. This implies that firms wishing to succeed in today's global business environment must make the appropriate HR investment to possess a unique and valuable human pool. Organisations emphasising quality goods for instance, must hire, train and reward employees to achieve such goals. Studies adopting the RBV theory in foreign MNCs, however, tend to neglect the importance of national culture or employee cultural orientations (Katou \& Budhwar, 2007).

In the case of Kenya, MNCs are deemed to be large companies because they have a workforce of 100 and above In this regard Kenya has about 50 large foreign manufacturing MNCs (Kenya Association of Manufacturers [KAM], 2007), and most of them are located in the large urban areas (Kenya Industrial and Research Development Institute [KIRDI], 2005). The MNCs owned by foreigners and other larger firms, mainly owned by Kenyan Asian, enjoy higher market power, are more specialised, and have better access to credit than small firms. Firms located in Nairobi have a higher export inclination than firms located elsewhere. The informal manufacturing sector which employs more than 85 percent of the manufacturing workforce tends to be smaller, younger, owner-managed, and less productive (National Development Plan, 2002-2008). The MNCs are better placed than many other small companies to appreciate the value of human capital (Youndt, Snell, Dean \& Lepak, 1996). They have also invested much in production innovations such as advanced manufacturing technologies and machinery. In addition, they are in a position to contribute to the economic growth of development in developing countries because they can transfer and adopt cross-border 'best practices' World Bank, KIPPRA, CSAE, Oxford (2004).

Traditionally, both scholars and managers of multinational companieshave assumed the universality of management (Hodgetts \& Luthans, 2000). Hence, MNCs have a tendency to take the management concepts and techniques that work at home into other countries. Even though African countries have received a share of multinational companies' investments, MNCs operating in developing countries face challenges in implementing the Western SHRM practices (Mamman \& Adeoye, 2007). In this regard the universality perspective of SHRM practices, specifically, recruitment, training, staff appraisals, and compensation systems to improve organisational performance needs to be contextualised.

Although the most extensively used dependent variable in organisational research, organisational performance, 
still remains vague and loosely defined (Rogers \& Wright, 1998), performance has been traditionally conceptualised in terms of financial measures. Some scholars have, however, proposed a broader performance construct that incorporates non-financial measures including, amongst others, market share, product quality, and company image. Furthermore, despite the general belief that SHRM practices lead to organisational performance, such a one-way line of causation is unsatisfactory (Edwards \& Wright, 2001). There is evidence to show that the relationship between SHRM practices and organisational performance is not always one way. In fact in some cases it has been found that high performing firms can generate excellent SHRM practices (Huselid, 1995) rather that excellent SHRM practices leading to high performance in organisations. This has led some scholars to propose the consideration of intermediate linkages between SHRM practices and organisational performance. This implicit model assumes that motivation mediates the link between SHRM practices and organisational performance. However, only a few researchers (Guest, 2001; Katou \& Budhwar, 2007) have measured employee motivation to address its importance. To this end the following hypothesis is proposed:

$H_{1}$ : A positive relationship exists between SHRM practices and firm performance.

\section{Culture and strategic human resource management}

Extant literature (Aycan et al., 2007; Budhwar \& Debrah, 2004) indicates that the major differentiating factors between developed and developing countries, which have an impact on HRM, are contextual. The factors include economic and historical environments, and socio-cultural characteristics of the workplace and society. Research on MNCs has indicated that amongst these elements, national culture has generated more interest in the field of comparative HRM because cultures affects people's behaviors (Brewster \& Hegewisch, 1994). In this regard, multinational companies must be sensitive to the prevailing values and attitudes in the host country.

MNCs produce and sell goods and services on an international basis, often far from the domestic country (Aycan et al., 2007; Kirkman, Lowe \& Gibson, 2006). This often calls for the establishment of branches and subsidiaries outside their national boundaries. As a result, multinational companies offer opportunities to people of different cultures to interact. They are playing an increasing role in the global economy as firms continue to increase cross-border investments. As people from different cultures interact, difficulties may be experienced because behaviour is based on different expectations and is the result of different mental programs. Mental programs exert a pervasive, yet hidden influence on behavior (Hofstede, 1984). As a result of variation in mental programs, people often see situations differently and have different approaches and solutions even to similar problems.

Even though African countries have received a share of MNCs' foreign direct investments (FDI), most empirical studies that have been undertaken on the management of foreign MNCs are based on research carried out in the United States, Europe, and Asian countries (Blunt \& Jones, 1992; Katou \& Budhwar, 2007). Curiously, though, conclusions drawn from such studies have assumed a universal or ecological approach to management even where individual countries differ on the basis of culture. Cross-cultural research (Hofstede, 1984) shows that certain countries cluster along four specific cultural dimensions. Recent research (Fang, 2003; $\mathrm{Ng}$, Lee \& Soutar, 2007) assumes that the most cited cultural classifications in the Social Science Citation Index, is Hofstede's (1980a) Culture's Consequences: International Differences in Work-Related Values. Over two decades have passed since Hofstede's publication, which has inspired thousands of empirical studies and the use of his four cultural dimensions that were derived from his data (Hofstede, 1983).

\section{Dimensions of national culture}

Cultural value dimensions constitute the main criteria by which national cultures differ. In comparing cultures of different countries, cross-cultural researchers have mainly relied on examining cultural value dimensions that were originally developed by Hofstede (Blunt \& Jones, 1986; Hofstede, 1995).

Power distance: Power distance refers to the extent people accept that power in institutions and organisations is distributed unequally. The greater the power distance, the more accepting a society becomes of these inequalities. Most developing countries are associated with high power distance (HPD), whereas most developed countries are associated with low power distance (LPD). Employees in HPD countries are generally found to be afraid to question the authority of the managers. Research (Morris \& Pavett, 1992) shows that the efficacy of participation in HPD cultures is doubtful. Hence such employees are likely to view participatory management with fear, distrust and disrespect. Managers who encourage participation in these countries are likely to be seen as weak and incompetent. On the other hand, participation in decision-making is an important dimension of management in countries with LPD. For example, US organisations generally show more employee involvement and are considered to be more efficient and faster growing (Denison \& Mishra, 1995) than those in HPD cultures. Hofstede measures power distance in a Power Distance Index (PDI) (Hofstede, 1991, p. 26). The values and attitudes found at the national level contrast 'low-PDI countries' with 'high-PDI countries'.

Uncertainty avoidance: Uncertainty avoidance refers to the extent to which a culture programs its members to feel either uncomfortable or comfortable in unstructured situations (Hofstede, 2001). In Hofstede's study the sampled countries were each given a score on an Uncertainty Avoidance Index (UAI) (Hofstede, 1991, p. 113). The countries ranked as high UAI include Greece, Portugal, and Guatemala, and East Africa (Kenya). Amongst those with low UAI are Singapore, Jamaica, and Denmark. 
Individualism or collectivism: Individualism represents values in society in which the ties between individuals are loose. Everyone is expected to look after him or herself and his or her immediate family. Collectivism stands for a society in which people from birth onward are integrated into strong, cohesive in-groups, which throughout people's lifetime continue to protect them in exchange for unquestioning loyalty (Hofstede, 2001, p. 225). National differences in individualism are calculated in an Individualism Index (IDV) (Hofstede, 1991, p. 53). The highest IDV scores were found in the United States, Australia, and Great Britain. The lowest IDV scores were found in Guatemala, Ecuador, Panama and East Africa (Kenya).

Masculinity or femininity: Masculinity is a preference for achievement, heroism, assertiveness, and material success. Femininity is a preference for relationships, modesty, caring for the weak, and quality of life. Surveys on the importance of work goals show that women attach more importance to social goals such as relationships, helping others, and the physical environment, and men attach more importance to ego goals such as resources, careers and money (Hofstede, 1991). However, Hofstede's data revealed that the importance respondents attached to such feminine versus masculine work varied across countries as well as across occupations. Since the respondents were mostly men, Hofstede (1984, p. 54), suggested calling this dimension the Masculinity Index (MAS). Generally, developed Western countries were found to rank relatively high on the Masculinity Index (MAS) and those from developing countries were found to rank generally low on the MAS index. East Africa where Kenya is situated is amongst the low ranked MAS countries.

Hofstede's four cultural dimensions have been extensively used in investigations of the role of culture in management practices in different countries (Kirkman, Lowe \& Gibson, 2006; McCrae, Terracciano, Realo \& Allik, 2008; Smith, 2006). To establish generalisability for his studies, Hofstede used cross validations with different samples to include a total of 50 nations, amongst them East Africa, West Africa, and Arabic speaking countries ( $\mathrm{Ng}$ et al., 2007) and thefindings showed correlations of variables or indicators with four of his dimensions (Hofstede, 2006).

Even though several researchers ( $\mathrm{Ng}$ et al., 2007) have criticised Hofstede's dimensions as being derived from old data, lacking generalisability and being too condensed to capture culture, McCrae et al. (2008) have directed the critics to Hofstede's (2000, p. 1356) response that the IBM data were obtained from well-matched samples and that the dimensions found are assumed to have centuries-old roots. Only data which remain stable across two subsequent surveys are maintained and this data have since been validated against all kinds of external measurements: recent replications show no loss of validity.

In addition, Hofstede (2001) notes that 140 non-IBM data studies validated his cultural indexes ( $\mathrm{Ng}$ et al., 2007). This study does not use the other large-scale research programs of Global Leadership and Organisational Behaviour Effectiveness (GLOBE) (House, Hanges, Mansour, Dorfman \& Gupta, 2004) and Schwartz's personal value dimensions approach (Schwartz, 1994) because the former is a study of organisational leadership in a cultural context whereas the latter is a program on personal values. Moreover, recent cross-cultural research (McCrae et al., 2008; Peterson \& Castro, 2006) suggests that the effectiveness of the nine cultural dimensions of large scale research programs of Global Leadership and Organisational Behaviour (GLOBE) had serious limitations which the book's authors have to address before their use in cross-cultural management studies. The other framework built on Hofstede's value dimensions, Schwartz's approach based on personal values $(\mathrm{Ng}$ et al., 2007), is more appropriate than Hofstede's framework for use in non-work related contexts. Schwartz's approach does not deal specifically with national cultures or with business people. His unit of analysis was schools and the respondents were teachers and students.

Some cross cultural researchers such as Fang (2003) and Kirkman et al. (2006) have on the other hand raised questions about the validity and appropriateness of Hofstede's (1991) fifth cultural dimension of Long-term vs. Short-term orientation for use in different cultural contexts. These researchers argue that Confucian values underlying the concept are so Chinese that they appear disconcertingly strange not only to many Western readers but also to the Chinese themselves. On the basis of these concerns, this study only applied Hofstede's (1980a) four cultural dimensions on MNCs in Kenya to establish the influence of culture on the relationship between SHRM practices and firm performance.

\section{Culture and human resource management in Kenya}

Although Hofstede's empirical results have been replicated in different nations (Kirkman et al., 2006; McCrae et al., 2008) where his cultural framework has been accepted for describing differences amongst nations, little empirical research has used the Hofstede dimensions to investigate the effect of SHRM practices on performance in different cultural groups. Also research in this area has not been integrated into the possible linkages found in SHRM practices, cultural orientations, motivation, and firm performance in MNCs in developing countries, particularly Kenya. This issue constitutes a gap in knowledge.

Empirical research (Gray \& Marshall, 1998; Nyambegera et al., 2001) indicates that culture influences employees' reaction to management practices in Kenya. For instance, like in many African countries, subordinates receive instructions from their managers and when in doubt, wait for the managers to decide the way out (Bate, 1984, 1990). Kenyan managers, especially the old ones, like to be called 'boss' as an expression of awe and respect (Kamoche, 1992). This sense of 'them and us' demarcation brings about a dependency attitude. However, whilst such practices may make Kenyan 
employees feel powerless and fearful, those with a subjugated orientation may exhibit greater motivation to be involved in their job (Kamoche, 1992). Employees in high power distance countries such as Kenya may have learned to accept such differences in the firms and attempts by managers in MNCs to narrow the gap could impact employees' motivation negatively. Expecting a Kenyan employee to participate in a decision-making process in a multinational company where SHRM practices promote this behavior may create conflict between cultural values and the motivation to perform. On this basis the following hypotheses are also posited:

$H_{2}$ : Employee cultural orientations affect the strength of the relationship between SHRM practices and employee motivation.

\section{$H_{3}$ : Employee motivation mediates the relationship between SHRM practices and firm performance.}

This study proposes a novel conceptual model linking these variables by introducing employees' cultural orientations to mediate the relationship between SHRM practices and motivation. A study by Mendonca and Kanungo (1994) shows that the socio-cultural environment affects employees' beliefs and values; and hence behavior towards SHRM practices.

The diagram in Figure 1 suggests a direct link between SHRM practices and performance as illustrated by arrow 1. Most studies hypothesise a direct link between SHRM practices and performance (Edwards \& Wright, 2001). However, sound theoretical development that explains how such SHRM practices operate is absent (Becker \& Gerhart, 1996). Arrow 2 indicates that employees' cultural orientations mediate the relationship between SHRM practices and motivation. Studies assert that the socio-cultural environment affects both employees' and managers' beliefs and values, and hence behavior towards SHRM practices. Arrow 3a shows that SHRM practices do not directly affect performance, but that there are variables that mediate between SHRM practices and organisational performance (Dimba \& K'Obonyo, 2009). Motivation is a mediating factor by which SHRM practices have an impact on organisation performance (Gerhart, 2005) - arrow $3 b$.

The use of this model (Figure 1) allows for the incorporation of more recent ideas concerning SHRM practices, other related variables and work performance. The model also reflects complexities of interrelationships and how employees'

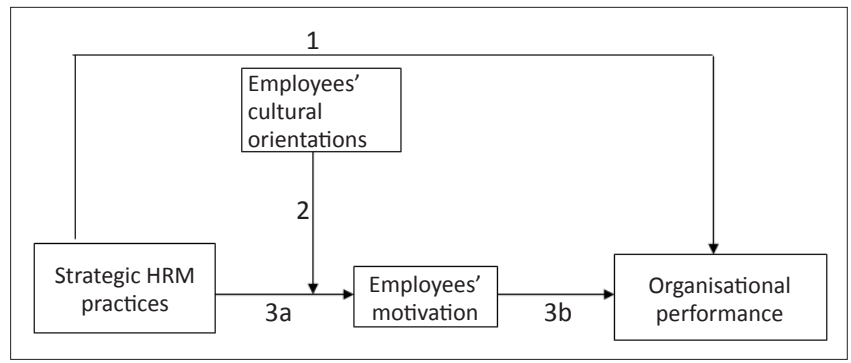

FIGURE 1: Conceptual model of the relationships amongst SHRM practices, employee cultural orientations, motivation and firm performance. cultural orientations are linked to SHRM practices, employees' motivation and firm performance. From the literature it is apparent that the relationships between the four variables (SHRM practices, cultural orientations, employees' motivation, and firm performance) in MNCs have not been examined within the Kenyan context. That is, their combined effect on firm performance has not been previously examined on MNCs operating in Kenya.

\section{Research design Research approach}

A multi-method empirical approach involving both surveys and interviews was used to decipher the relationship between SHRM practices, employees' motivation and firm performance. This triangulation approach of surveys and interviews provided an opportunity to develop a broadbased understanding of the relationships amongst the key variables used in the study.

\section{Research method}

First, a cross-sectional survey of MNCs was undertaken to determine specific parameters across the respondents. On the basis of responses to the questionnaire, the researcher selected a sample of six MNCs for the interviews. The six MNCs were chosen by a simple random method from the twenty seven (27) companies that had completed the questionnaire.

\section{Research participants}

The target population was large foreign multinational manufacturing companies operating in Kenya, which were members of the Kenya Association of Manufacturers. The main reason for the choice of large foreign MNCs was that these firms are likely to have elaborate SHRM practices and also be able to transfer those practices to developing countries (Mamman \& Adeoye, 2007). Another reason for the choice of MNCs was because research on large manufacturing companies in developed countries shows that SHRM practices are linked to performance (Bae, Chen \& Lawler, 1998; Katou \& Budhwar, 2006, 2007). Because of the small number of foreign MNCs in Kenya, the study took a complete survey and all fifty (50) MNCs were included in the study.

The respondents included specialist HR managers, line managers (marketing managers and production managers), and three employees who were not in a management position - one from each of the functional departments represented by three managers (six) from each organisation. The respondents totalled 300 from 50 organisations. The inclusion of employees' perspectiveswas based on the argument that employees are most affected by the way their immediate manager treats them, as this determines their day-to-day experiences (Richardson \& Thompson, 1999). Further support for their inclusion is the fact that less research has been done amongst employees as compared to managers and yet employees play a big role in the day to day 
implementation of strategies (Hall, 2004; Kamoche, 2001). Without knowing how employees interpret SHRM practices, a vital link was missing in the research process. The selection criterion used for the employees was years of service in the organisation. A longer serving employee was assumed to have acquired more work experience and was likely to give more relevant responses than a less experienced employee (Dessler, 2005). The rationale for choosing management respondents was based firstly on the fact that HR strategies are usually formulated by management and professional employees rather than lower level employees; and secondly, inclusion of other non-HR managers was expected to reduce response bias by gauging alternative perspectives (Guest, 2001; Wright, McMahan \& McWilliams, 2001; Youndt et al., 1996).

\section{Measuring instruments}

This study used the questionnaire developed by both Hofstede (1980a) and Huselid (1995) and modified by the researcher to collect data. Hofstede's (1980a) instrument had been used previously in West Africa, East Africa, and Arab speaking countries. Huselid's instrument contains measures for SHRM practices, motivation and performance and had also been used in the United States in nearly 1000 large firms. Some previous studies (Bae, Chen \& Lawler, 1998), using similar scales to measure HR practices, found Cronbach's alpha reliability coefficients of 0.70 in four areas of HR practices, that is, recruitment and selection, training and development, participation and rewards, whilst other studies (Delaney \& Huselid, 1996) reported alpha coefficients of between 0.70 and 0.91 for different HR practices.Regarding the level of the importance of motivation concerning the employees' job and the organisation they worked for, Delaney and Huselid (1996), in particular, found positive relationships between SHRM practices, motivation and performance.

A likert scale of 1 to 5 (Appendix II) was used to measure the level of the problems for most of the cultural values and also the level of general beliefs on cultural issues. Such a scale has also been used by Hofstede (1980a, 1980b). Questions touched specifically on cultural values (measured by Power Distance), and general beliefs (measured by Uncertainty Avoidance, Masculinity or Femininity, Individualism or Collectivism).

\section{Research procedure}

Essentially, the study utilised an interview data collection technique that involved oral questioning of respondents. Respondents were asked to give information about organisational performance on the quality of product, firm image, and interpersonal relations. In effect this is a perceptual measure of firm performance and previous scales used by Huselid (1995) and Delaney and Huselid (1996) had shown Cronbach's alpha reliability coefficients of between 0.75 and 0.88 .

\section{Reliability}

The measurement scales for HR practices and motivation presented above were adopted with modifications from the instruments that were developed by Huselid (1995). For this reason, the researcher tested the scales again for reliability using pilot data from nine respondents from one large foreign manufacturing multinational company operating in Kenya. This company was not included in the target population. The Cronbach's alpha coefficients obtained, confirmed the reliability of the measured variables with a coefficient of 0.70 . This coefficient is fairly large and one could, therefore, conclude that the measurement scales were reliable.

\section{Results \\ Quantitative data}

The hypotheses were tested using Pearson's product moment correlation and simple regression analyses.

$H_{1}$ : A positive relationship exists between SHRM practices and firm performance.

Table 1 shows that amongst the SHRM practices, training and development $(r=0.4$, at $p<0.01)$ had the strongest positive correlation (as indicated by ' $r$ ') between SHRM practices and performance. Next were the compensation systems $(r=0.3$, at $p<0.01)$ and performance appraisal $(r=0.2$, at $p<0.01)$, and lastly, flexible work arrangements $(r=0.3$, at $p<0.05)$. Firm performance was not correlated with recruitment and selection. This implies that if at all there was a link between these SHRM practices and performance, it was indirect through another variable which is not part of this study.

The results in Table 1 are consistent with those in Table 3 where training and development and compensation systems have a significant effect on performance. Training and development and compensation systems alone explain up to $20 \%$ of variance in firm performance $\left(R^{2}=0.2\right)$. It is evident in Table 3, that a unit increase in training and development, holding compensation systems constant, resulted in a $30 \%$ change (increase) in organisational performance; whereas a $20 \%$ increase in performance was achieved with every additional unit in compensation, holding training and development constant. These findings lead to the acceptance

TABLE 1: Results of the correlation analysis for the relationship between SHRM practices and organisational performance.

\begin{tabular}{ll}
\hline SHRM practices & $r$ \\
\hline Recruitment and hiring & 0.0 \\
Training and development & $0.4 \dagger$ \\
Performance appraisal & $0.2 \dagger$ \\
Compensation systems & $0.3 \dagger$ \\
Flexible work arrangements & $0.3 \ddagger$ \\
\hline
\end{tabular}

\section{Flexible work arrangements}

SHRM, strategic human resource management; $r$, linear correlation coefficient.

$n=161$.

$\dagger, \alpha<0.01$.
$t, \alpha<0.05$.

TABLE 2: Correlations between SHRM practices and motivation.

\begin{tabular}{ll}
\hline SHRM practices & $\boldsymbol{r}$ \\
\hline Recruitment and selection & 0.0 \\
Training and development & $0.4 \dagger$ \\
Performance appraisal & $0.5 \dagger$ \\
Compensation systems & $0.5 \dagger$ \\
Flexible work arrangements & $0.3 \dagger$ \\
\hline SHRM, strategic human resource management; $r$, linear correlation coefficient. \\
$n=161$. \\
$\dagger, \alpha<0.01$.
\end{tabular}


of the hypothesis that there is a positive relationship between SHRM practices and firm performance.

$H_{2}$ : Employee cultural orientations affect the strength of the relationship between SHRM practices and employee motivation.

The results are presented in Tables 2, 4 and 5. As shown in Table 2, all the strategic human resource practices, except recruitment and selection, are positively and significantly correlated with motivation. This suggests that the use of best HR practices in training and development, performance appraisal, compensation and flexible work arrangements has a significant positive influence on employees' motivation. To test for the mediating effects of employee cultural orientations (measured by power distance) on the relationship between strategic HRM practices and motivation, the coefficient of determination $\left(R^{2}\right)$ is obtained when cultural orientations were in the regression equation and when they were not. The two results were compared. The differences were attributed to the mediating influence of employee cultural orientations. The results are presented in Table 5.

It is noted from the table that $R^{2}$ decreased by $10 \%$ from $40 \%$ to $30 \%$ but remained the same at $40 \%$, respectively, when cultural values and cultural beliefs were introduced into the regression equation. This indicates that the relationship between strategic HRM practices and employee motivation is weakened by cultural values, whilst cultural beliefs did not affect the relationship. Therefore, the hypothesis that the relationship between strategic HRM practices and motivation depends on employees' cultural orientations is accepted for the cultural values but not for the cultural beliefs attribute.

$\mathrm{H}_{3}$ : Employee motivation mediates the relationship between SHRM practices and firm performance.

TABLE 3: Results of the regression analysis of the effect of SHRM practices and motivation, on organisational performance.

\begin{tabular}{lccc}
\hline Variable & \multicolumn{3}{c}{ SHRM practices } \\
\cline { 2 - 4 } & $\begin{array}{c}\text { Training and } \\
\text { development }\end{array}$ & $\begin{array}{c}\text { Compensation } \\
\text { systems }\end{array}$ & Motivation \\
\hline$\beta$ & 0.3 & 0.2 & 0.3 \\
$t$-value & 4.0 & 2.3 & 3.3 \\
$p$-value & $<0.01$ & $<0.01$ & $<0.01$ \\
$R^{2}$ & 0.2 & 0.2 & 0.1 \\
\hline
\end{tabular}

SHRM, strategic human resource management.

$\beta$, value of the estimated regression coefficient (For influential predictor variables, the value $\beta$, value of the estimated regression coefficient (For influential predictor variables, the value of beta differs from 0 significantly. For insignificant 0 ); $t$-value, measure of importance of the predictor variables (The $t$-value of an influentia predictor variable deviates significantly from 0 ; the $t$-value of an insignificant predictor variable is close to 0); $p$-value, measure of importance of the predictor variables (At the $5 \%$ level of significance, for influential predictor variables, the $p$-value $<0.05$; and for insignificant variables, the $p$-value is 0.05 or above); $R^{2}$, measure of variation explained by the fitted line of regression.
As indicated in Table 2, all the SHRM practices, except recruitment and selection, are positively and significantly correlated with motivation. It is noted from Table 3 that motivation alone accounts for $10 \%\left(R^{2}=0.1\right)$ of variation in firm performance. Motivation had thus a significant effect on performance $(\beta=0.3, t=3.3, p<0.01)$. Similarly, Table 3 shows that the best predictors of firm performance as far as SHRM practices were concerned were training and development $(\beta=0.3, t=4, p<0.01$ in respect of training and development) and compensation systems $(\beta=0.2, t=2.3$, $p<0.01$ in respect of compensation). These two SHRM practices alone explained up to $20 \%$ of variance in firm performance $\left(R^{2}=0.2\right)$. Consequently, motivation and SHRM practices accounted for 0.30 or $30 \%$ of firm performance $(0.2+0.1)$. This implies that motivation is a necessary intermediate outcome for the relationship between SHRM practices and firm performance as it had contributed 10\% of the variation in performance. Therefore, the hypothesis that motivation mediates the relationship between SHRM practices and firm performance is accepted.

\section{Qualitative data}

This section analysed the findings of the interviews with heads of human resource, marketing and production departments, and employees from six firms as a follow-up on issues arising from the questionnaire responses that required clarification from additional data. The interviews expanded the information furnished in the questionnaire on the SHRM practices, motivation, and firm performance. Minitab for regression, statistical data analysis software, was used to convert qualitative data to quantitative data.

The data from the interviews that are relevant to hypothesis 2 are presented in Table 7. Although these data are solely descriptive in nature, they were used to corroborate the results of inferential statistical tests presented in Table 5, which were based on data obtained using the survey questionnaire. Firstly, the results were described in respect of cultural values and secondly, with regards to cultural beliefs.

\section{Cultural orientations (Values)}

As shown in Table 6, the relationship between SHRM practices and motivation is higher before the cultural orientation or values measured by power distance (PD) isintroduced than after. This is true for all the three nominated SHRM practices, namely, training and development $(62.50 \%$ before and $58.30 \%$ after $)$, staff appraisal $(83.30 \%$ before and $58.30 \%$ after $)$ and compensation systems (79.16\% before and $58.30 \%$ after) thus underlining the importance of power distance (PD) as

TABLE 4: Regression analysis of factors influencing motivation at work.

\begin{tabular}{|c|c|c|c|c|c|c|c|}
\hline \multirow[t]{2}{*}{ Variable } & \multicolumn{3}{|c|}{ SHRM practices } & \multirow{2}{*}{$\begin{array}{l}\text { Cultural values } \\
\text { (Power distance) }\end{array}$} & \multicolumn{3}{|c|}{ Cultural beliefs } \\
\hline & $\begin{array}{c}\text { Training and } \\
\text { development }\end{array}$ & $\begin{array}{c}\text { Compensation } \\
\text { systems }\end{array}$ & $\begin{array}{l}\text { Performance } \\
\text { appraisal }\end{array}$ & & $\begin{array}{l}\text { Collectivism or } \\
\text { individualism }\end{array}$ & $\begin{array}{l}\text { Uncertainty } \\
\text { avoidance }\end{array}$ & $\begin{array}{l}\text { Masculinity or } \\
\text { femininity }\end{array}$ \\
\hline$\beta$ & 0.3 & 0.3 & 0.2 & 0.3 & 0.3 & 0.3 & 0.2 \\
\hline$p$-value & $<0.01$ & $<0.01$ & $<0.05$ & $<0.01$ & $<0.01$ & $<0.01$ & $<0.05$ \\
\hline
\end{tabular}

SHRM, strategic human resource management.

$R^{2}=0.4$.

$\beta$, value of the estimated regression coefficient (For influential predictor variables, the value of beta differs from 0 significantly. For insignificant variables, the value of beta is close to 0 ); $t$-value,

$\beta$, value of the estimated regression coefficient (For influential predictor variables, the value of beta differs from 0 significantly. For insignificant variables, the value of beta is close to 0); $t$-value,
measure of importance of the predictor variables (The $t$-value of an influential predictor variable deviates significantly from 0 ; the $t$-value of an insignificant predictor variable is close to 0 ); $p$-value, measure of importance of the predictor variables (The $t$-value of an influential predictor variable deviates significantly from 0 ; the $t$-value of an insignificant predictor variable is close to 0 ); $p$-value,
measure of importance of the predictor variables (At the $5 \%$ level of significance, for influential predictor variables, the $p$-value $<0.05$; and for insignificant variables, the $p$-value is 0.05 or above); 
TABLE 5: Regression results for the factors influencing the relationship between SHRM practices and motivation at work.

\begin{tabular}{lcccc}
\hline Variable & $\begin{array}{c}\text { Cultural values } \\
\text { (Power distance) }\end{array}$ & \multicolumn{3}{c}{ Cultural beliefs } \\
\cline { 3 - 5 } & $\begin{array}{c}\text { Collectivism or } \\
\text { individualism }\end{array}$ & $\begin{array}{c}\text { Uncertainty } \\
\text { avoidance }\end{array}$ & $\begin{array}{c}\text { Masculinity or } \\
\text { femininity }\end{array}$ \\
\hline${ }^{*} R^{2}$ before & 0.4 & 0.4 & 0.4 & 0 \\
$R^{2}$ after & 0.3 & 0.4 & 0.4 & 0 \\
Change in $R^{2}$ & -0.1 & 0.4 & 0.4 & 0 \\
\hline
\end{tabular}

Source: ${ }^{*}$ This table is extracted from Table 4

SHRM, strategic human resource management.

$R^{2}$, measures the increase in the value of $R^{2}$ resulting from the inclusion of the newly introduced variable into the existing model. This is different from the value of $R^{2}$ corresponding to the final or optimal regression model.

TABLE 6: Effect of cultural orientations on the motivation of employees of MNCs in Kenya.

\begin{tabular}{lcc}
\hline National cultural dimensions & $\boldsymbol{n}$ & Frequency in $\%$ \\
\hline 1. Power distance & & \\
Are you generally afraid to disagree with your superior? & & \\
Yes & 4 & 16.70 \\
No & 6 & 25.00 \\
Yes and No & 14 & 58.30 \\
Total & $\mathbf{2 4}$ & $\mathbf{1 0 0 . 0 0}$
\end{tabular}

2. Individualism or collectivism

Would you prefer working for an organisation that is directly concerned with your private life, for instance your family matters?

$\begin{array}{lcc}\text { Yes } & 21 & 87.50 \\ \text { No } & 1 & 4.17 \\ \text { Yes and No } & 2 & 8.33 \\ \text { Total } & \mathbf{2 4} & \mathbf{1 0 0 . 0 0}\end{array}$

\section{Uncertainty avoidance}

Do you think company rules should not be broken even when it is in the company's best interest?

$\begin{array}{lcc}\text { Yes } & 9 & 37.50 \\ \text { No } & 9 & 37.50 \\ \text { Yes and No } & 6 & 25.00 \\ \text { Total } & \mathbf{2 4} & \mathbf{1 0 0 . 0 0}\end{array}$

\section{Masculinity or femininity}

Would you agree with the statement: 'Competition amongst employees usually does more harm than good'?

\begin{tabular}{lcc} 
Yes & 16 & 66.70 \\
No & 8 & 33.30 \\
Yes and No & 0 & 00.00 \\
Total & $\mathbf{2 4}$ & $\mathbf{1 0 0 . 0 0}$ \\
\hline
\end{tabular}

TABLE 7: The moderating influence of cultural orientations on the relationship between SHRM practices and motivation.

\begin{tabular}{lcccccc}
\hline SHRM practice & \multicolumn{2}{c}{ Cultural orientation (Values) } & & \multicolumn{2}{c}{ Cultural beliefs } \\
\cline { 2 - 3 } \cline { 6 - 6 } & Before (\%) & After (\%) & & Before (\%) & After (\%) \\
\hline Training and & 62.5 & 58.3 & & 62.5 & 87.5 \\
development & - & - & & 62.5 & 37.5 \\
& - & - & & 62.5 & 66.7 \\
Staff appraisal & 83.3 & 58.3 & & 83.3 & 87.5 \\
& - & - & & 83.3 & 37.5 \\
Compensation & - & - & & 83.3 & 66.7 \\
systems & 79.16 & 58.3 & & 79.16 & 87.5 \\
& - & - & & 79.16 & 37.5 \\
& - & - & & 79.16 & 66.7 \\
\hline
\end{tabular}

Source: This table is extracted from Table 6

SHRM, strategic human resource management.

acultural dimension or cultural value in making these SHRM practices more efficient.

The descriptive statistics in Table 7 and the results of statistical tests in Table 5 are consistent. That is, in Table 5,
$R^{2}$ declined from 0.4 to 0.3 when cultural orientations were introduced in the relationship between all three nominated SHRM practices and motivation. This is consistent with the descriptive results in Table 7 where there is a decline from $62.50 \%$ to $58.30 \%$ in respect of training and development; from $83.30 \%$ to $58.30 \%$ in respect of staff appraisal; and from $79.16 \%$ to $58.30 \%$ in respect of compensation systems.

\section{Cultural orientations (Beliefs)}

In order to interpret the results in Table 6 and Table 7, the relationship between SHRM practices and motivation is considered to be consistent if the majority of the respondents: (1) preferred working for an organisation that is directly concerned with their private life such as family matters; (2) felt that company rules should not be broken even when it is in the company's best interests; and (3) agreed that competition amongst employees usually does more harm than good. It is noted from Table 7, that the relationship between SHRM practices and motivation before the introduction of cultural orientations (beliefs) as measured by Individualism or Collectivism (INDCOL), Uncertainty Avoidance (UA), and Masculinity or Femininity (MF) is consistent with the relationship between the nominated SHRM practices and motivation after the introduction of these cultural dimensions. This is true for all SHRM practices as demonstrated below.

\section{Training and development}

Firstly, training and development was rated at $62.5 \%$ before cultural orientation or the dimension ofIndividualism or Collectivism was introduced and at $87.5 \%$ after this latter cultural dimensions were introduced; secondly, training and development was rated at $62.5 \%$ before cultural orientation or the dimension of Uncertainty Avoidance was introduced and at $37.5 \%$ after this latter cultural dimension was introduced; thirdly, training and development was rated at $62.5 \%$ before the cultural dimension of Masculinity or Femininity was introduced and at $66.7 \%$ after this latter cultural dimension was introduced. The implications are that these particular cultural dimensions or orientations do not significantly affect the relationship between the SHRM practice of training and development and employee motivation.

\section{Staff appraisal}

Firstly, staff appraisal was rated at $83.3 \%$ before cultural orientation or the dimension of Individualism or Collectivism was introduced and at $87.5 \%$ after this latter cultural dimension was introduced; secondly, staff appraisal was rated at $83.3 \%$ before cultural orientation or the dimension of Uncertainty Avoidance was introduced and at 37.5\% after this latter cultural dimension was introduced; thirdly, staff appraisal was rated at $83.3 \%$ before the cultural dimension of Masculinity or Femininity was introduced and at $66.7 \%$ after this latter cultural dimension or orientation was introduced. The implications are that these particular cultural dimensions or orientations do not significantly affect the relationship between the SHRM practice of Staff Appraisal and employee motivation. 


\section{Compensation systems}

Firstly, compensation systems wererated at $79.16 \%$ before cultural orientation or the dimension of Individualism or Collectivism (INDCOL) was introduced and at $87.50 \%$ after this dimension was introduced; secondly, compensation systems were rated at $79.16 \%$ before cultural orientation or the dimension of Uncertainty Avoidance (UA) was introduced and at $37.50 \%$ after this particular dimension was introduced; thirdly, compensation systems were rated at $79.16 \%$ before the cultural dimension of Masculinity or Femininity (MF) was introduced and at $66.70 \%$ after this latter cultural dimension was introduced. From the foregoing analysis, the three cultural dimensions of INDCOL, UA and MF did not appear to have a significant effect on the relationship between the SHRM practice of compensation systems and employee motivation.

The descriptive statistics in Table 7 and the results of statistical tests in Table 5 are consistent. That is, in Table 5, $R^{2}$ remained the same (0.4) before and after the three (3.0) cultural orientation dimensions were introduced in the relationship between SHRM practices and motivation. This is consistent with the descriptive results in Table 6 where the relationship between SHRM practices and motivation showed consistency as explained above. In general, the findings from interview data summarised in Table 6 and Table 7 corroborate information obtained from questionnaire data in Table 5 where $\left(R^{2}\right)$ decreased by $10 \%$ to $30 \%$ but remained the same at $40 \%$, respectively, when the above mentioned cultural orientationswere introduced into the regression equation.

Overall, the results support the notion that the relationship between SHRM practices and motivation is moderated by cultural orientations only when cultural values as measured by power distance were considered; but did not support the view when cultural beliefs (measured by Collectivism or Individualism, Uncertainty Avoidance, and Masculinity or Femininity) were introduced into the regression. Further implications of this finding are discussed below.

\section{Discussion}

This study sought to investigate the extent to which employee cultural orientations affect the link between SHRM practices and firm performance in large foreign manufacturing multinational companies in Kenya. Large foreign multinational companies have generally applied SHRM practices without adaptation when trying to improve employee performance even though resource-based perspectives argue for the consideration of employees' cultural orientations. This study instead supports the notion that the relationship between SHRM practices and firm performance is distinctly moderated by the cultural dimension of 'power distance' through motivation. More specifically, the study addressed three hypotheses as elaborated here-under.

The first hypothesis $\left(H_{1}\right)$ stated that a positive relationship exists between SHRM practices and firm performance. To this end the study found thatamongst the SHRM practices, training and development had the strongest positive correlation between SHRM practices and performance, followed by compensation systems and performance appraisal and lastly, flexible work arrangements. Firm performance is not correlated with recruitment and selection. This implies that if at all there is a link between these SHRM practices and performance, it is indirect and perhaps even through another variable which was not part of this study.

The second hypothesis $\left(\mathrm{H}_{2}\right)$ stated that employee cultural orientations affect the strength of the relationship between SHRM practices and employee motivation. The study found that a positive relationship exists between SHRM practices and firm performance. In fact, the study significantly supports this hypothesis in that it found that the majority of the strategic human resource (SHRM) practices save for recruitment and selection, were positively and significantly correlated with employee motivation.

The third hypothesis, $\left(H_{3}\right)$ stated that Employee motivation mediates the relationship between SHRM practices and firm performance. This hypothesis is supported, since the most important relationships tested showed that motivation is a necessary intermediate outcome for the relationship between SHRM practices and firm performance as it had contributed to more than $10 \%$ of the variation in performance.

Findings indicate that the relationship between SHRM practices and firm performance depends to a greater extent on employee cultural orientations (when power distance is considered). This finding is important because it is consistent with earlier works and advocates who disapproves of the notion of a given set of best practices as the only means of assessing SHRM practices. For example, Gerhart (2005, p. 178) argues that it seems unlikely that one set of SHRM practices will work equally well no matter the context. This is also significant given that contextual variables, particularly national culture or employee cultural orientations have been found in various studies to have an influence on the choice of SHRM strategies (Aycan et al., 2007; Nyambegera et al., 2001).

The results of this study were expected, based on previous works, the fact that the relationship between strategic HRM practices and employee motivation is weakened only by cultural values, and not by cultural beliefs, presented an interesting departure from expected findings. Consequently, this limited the hypothesis that the relationship between strategic HRM practices and motivation depends on employees' overall cultural orientations. This unexpected finding may lie in the fact that power distance may be the most relevant and pertinent cultural value for Kenyans working within organisations that are predominantly predicated on western styles of operation.

\section{Conclusions and recommendations}

Based on the major findings of this study, the following conclusions were made. 
The applicability of Western nations' models of SHRM practices in MNCs operating in developing countries does raise important questions, because the relationship between the use of SHRM practices and firm performance did not hold across the five bundles of what were considered to be 'high performance work practices' (HPWP). In the context of SHRM models developed by Western nations these include, recruitment and selection, training and development, performance appraisals, compensation systems, and flexible work arrangements (Katou \& Budhwar, 2006, 2007).

This study supported the notion that the relationship between SHRM practices and motivation is moderated by cultural orientations when cultural values (measured by power distance) were considered; however, this was not the case when cultural beliefs (measured by Collectivism or Individualism, Uncertainty Avoidance, and Masculinity or Femininity) wereintroduced into the regression. Hence, the results of this study partially corroborated those of previous studies that the relationship between SHRM practices and motivation depends on cultural orientations (Aycan et al., 2007; Horwitz et al., 2006).

Based on these conclusions, the following recommendation is made: firms should focus on more than the five bundles (recruitment and selection, training and development, compensation systems, staff appraisals and flexible work arrangements) to give a wider scope of practices. A wider scope is necessary, because it could, for instance, help MNCs to avoid practices that conflict with traditional practices in the host country.

The limitations of this study constrain the interpretation of the findings and point to several issues for future research. Firstly, this study only examined cross-sectional differences amongst large manufacturing multinational firms. Gaining a clearer understanding of the relationships between SHRM practices, cultural influences and motivation would require a longitudinal analysis.

Secondly, this study explicitly examined the influence of cultural values and beliefs on the relationship between SHRM practices, motivation, and firm performance. Drawing conclusions from the use of only one variable (culture) may not present the right picture. The difficulty here is finding an appropriate portrayal of the manner in which a nation's wealth is interwoven with the multitude of other factors that contribute both to cultural stability and cultural change.

This study revealed a number of areas for further research. Empirical studies are made to examine the applicability of models of SHRM practices formulated by Western nations in developing countries. Hofstede (1993) and Brewster et al. (1994) are of the opinion that the dynamic international business environment demands appropriate information and guidance to develop relevant management practices. To obtain more interesting and revealing results of cultural orientations, the longitudinal research design might be used by future researchers. It is suggested that future researchers accommodate other major differentiating factors, such as economic influence (Sundaram \& Black, 1992; Van de Vliert, 2006). The creation of national cultures must entail reference to historical factors, and must acknowledge wealth as being both a cause and an effect of other elements in a nation's adaptation to its context.

\section{Acknowledgements}

The lead author would like to acknowledge the assistance provided by the Faculty of Management and Commerce, Strathmore University, Kenya in supporting and providing resources for this study.

\section{Competing interests}

The authors declare that they have no financial or personal relationship(s) which may have inappropriately influenced them in writing this article.

\section{Authors' contributions}

B.D. (Strathmore University)was responsible for conceiving and conducting the fieldwork that resulted in an earlier draft of this work. R.R. (Tshwane University of Technology) contributed additional literature and undertook most of the writing including addressing reviewers' and the copy editor's concerns.

\section{References}

Aycan, Z., Al-Hamadi, A.B., Davis, A., \& Budhwar, P. (2007). Cultural orientations and preference for HRM policies and practices.The case of Oman. International Journal of Human Resource Management, 18, 11-32. http://dx.doi. org/10.1080/09585190601068243

Bae, J., Chen, S., \& Lawler, J. (1998). Variations in hrm in Asian countries: MNC Home Country and Host Country Effects. International Journal of Human Resource Management, 9(4), 653-670. http://dx.doi.org/10.1080/095851998340946

Bate, P. (1984). The impact of organizational culture on approaches to organizational problem-solving. Organization Studies, 5(1), 43-66. http://dx.doi. org/10.1177/017084068400500103

Bate, P. (1990). Using the culture concept in an organization development setting The Journal of Applied Behavioral Science, 26(1), 83-106. http://dx.doi. org/10.1177/002188639002600108

Becker, B., \& Gerhart, B. (1996). The impact of human resource management on organizational performance: progress and prospects.Academy of Management Journal, 39(4), 779-801. http://dx.doi.org/10.2307/256712

Blunt, P., \& Jones, M. (1992). Managing Organizations in Africa. Berlin, Germany: Walter de Gruyter and Company. http://dx.doi.org/10.1515/9783110850031

Blunt, P., \& Jones, M. (1986). Managerial motivation in Kenya and Malawi: A crossculturalcomparison. The Journal of African Studies, 24(1), 165-175. http://dx.doi. org/10.1017/S0022278X00006790

Brewster, C., \& Hegewisch, A. (1994). Human resource management in Europe: Issues andopportunities. In C. Brewster, \& A. Hegerwisch (Eds.), Policy and practice in European human resource management: The Price Waterhouse Cranfield Survey. London: Routledge.

Budhwar, P.S., \& Debrah, Y.A. (2004). Human Resource Management in Developing Countries. London: Routledge. PMid:21783596

Delaney, J.T., \& Huselid, M.A. (1996). The impact of human resource management practices on perception of organizational performance. Academy of Management Journal, 39(4), 949-969. http://dx.doi.org/10.2307/256718

Denison, D.R., \& Mishra, A.K., (1995). Toward a theory of organizational culture and effectiveness. Organization Science, 6, 204-23. http://dx.doi.org/10.1287/ orsc.6.2.204

Dessler, G. (Ed). (2005). Establishing Pay Plans: Human Resource Management, Pearson Prentice Hall: Upper Saddle River, New Jersey.

Dimba, B.A. (2010). Strategic human resource management practices: Effect on performance. AfricanJournal of Economic and Management Studies, 1(2), 128137. http://dx.doi.org/10.1108/20400701011073455

Dimba, B., \& K'Obonyo, P. (2009). The effect of strategic human resource management practices on performance of manufacturing multi-national companies in Kenya: a moderating role of employee cultural orientations. In S. Simon (Ed.), Repositioning African Business and Development for the 21st Century of 2009. In Proceedings of an International Academy of African Business and Development, Kampala, Uganda, 19-23 May 2009, (pp. 403-408). 
Edwards, P., \& Wright, M. (2001). High-involvement work systems and performance outcomes: The strength of variable, contingent and context-bound relationships. International Journal of Human Resource Management, 12(4), 568-585. http:// International Journal of Human
dx.doi.org/10.1080/713769651

Fang, T. (2003). A critique of Hofstede's fifth national culture dimension. International Journal of Cross Cultural Management, 3, 347-368. http://dx.doi. org/10.1177/1470595803003003006

Gerhart, B. (2005). Human resource management and business performance: Findings, unanswered questions and an alternative approach. Management Review, 16, 174-185.

Gray, K.R., \& Marshall, K.P. (1998). Kenyan and Korean management orientations on Hofstede's cultural values. Multinational Business Review, 6(2), 79-88.

Guest, D.E. (2001). Human resource management: When research confronts theory. International Journal of Human Resource Management, 12(7), 1092-1106. http:// dx.doi.org/10.1080/09585190110067837

Hall, L. (2004). HRM Practices and Employee and Organizational Performance A Critique of the Research and Guest's Model, Department of Business and Management, Manchester Metropolitan University, Cheshire.

Hofstede, G. (1980a). Culture's Consequences: International Differences in WorkRelated Value. Laguna Hills, California: Sage Publications.

Hofstede, G. (1980b). Wealth of Nations: Culture and Economic Growth. In S.D. Hunt (Ed.), (2002). (A General Theory of Competition, Resources, Competences,
Productivity, Economic Growth). (Marketing for a New Century). Sage Publications, productivity, $205-238$.

Hofstede, G. (1983). The cultural relativity of organizational Practices and theories. Journal of International Business Studies, 14(2), 75-89. http://dx.doi.org/10.1057/ palgrave.jibs.8490867

Hofstede, G. (1984). Motivation, Leadership and Organization: Do American Theories Apply Abroad? Organizational Dynamics, 9, 42-63. http://dx.doi. org/10.1016/0090-2616(80)90013-3

Hofstede, G. (1991). Cultures and organizations: Software of the mind. London: McGraw-Hill.

Hofstede, G. (1993). Cultural constraints in management theories. In J.T. Wren (Ed.) The leader's companion (pp. 253-270). New York: Free Press.

Hofstede, G. (1995). Cultures and organizations: Software of the mind. London: McGraw-Hill.

Hofstede, G. (2000). Cultures and organizations: Software of the mind. London: McGraw-Hill.

Hofstede, G. (2001). Culture's Consequences: Comparing Values, Behaviors, Institutions, and Organizations across Nations. Thousand Oaks, California: Sage.

Hofstede, G. (2006). Cultures and organizations: Software of the mind. London: McGraw-Hill.

Hodgetts, R.M., \& Luthans, F. (2000). International Management: Culture, Strategy, and Behavior. McGraw-Hill: New York, New York.

Horwitz, F.M., Heng, C.T., Quazi, H.A., Nonkwelo, C., Roditi, D., \& Van Eck, P. (2006) Human resource strategies for managing knowledge workers: an Afro-Asian comparative analysis. International Journal of Human Resource, 17(5), pp. 775 811. http://dx.doi.org/10.1080/09585190600640802

House, R.J., Hanges, P.J., Mansour, J., Dorfman, P.W., \& Gupta, V. (Eds.). (2004). Culture, Leadership and Organizations: The GLOBE Study of 62 Societies. Thousand Oaks, California: Sage.

Huselid, M.A. (1995). The impact of human resource management practices on turnover, productivity, and corporate financial performance. Academy of Management Journal, 38, 635-672. http://dx.doi.org/10.2307/256741

Kamoche, K. (1992). Human resource management: An assessment of the Kenyan Case. InternationalJournal of Human Resource Management, 3(3), 497-521. $\mathrm{http}: / / \mathrm{dx}$.doi.org/10.1080/09585199200000162

Kamoche, K. (2001). Understanding Human Resource Management, Open University Press: Buckingham.

Katou, A. \& Budhwar, P. (2006). Human resource management systems on organizational performance: A test of mediating model in the Greek manufacturing context. International Journal of Human Resource Management, 19(7), 1223context. International Journal of Human Resource M
1253. http://dx.doi.org/10.1080/09585190600756525

Katou, A., \& Budhwar, P.S. (2007). The effect of human resource management policies on organizational performance in Greek manufacturing. Thunderbird International Business Review, 49(1), 1-35. http://dx.doi.org/10.1002/tie.20129
Kenya Association of Manufacturers [KAM]. (2007). Directory Edition, Kenya Association of Manufacturers, Nairobi.

Kenya Industrial and Research Development Institute (KIRDI). (2005). Kenya Directory of Manufacturing Industries, Kenya Industrial and Research Development Institute, Nairobi.

Kirkman, B.L., Lowe, K.B., \& Gibson, C.B. (2006). A Quarter century of Culture's consequences: A review of empirical research incorporating Hofstede's cultural values framework. Journal of International Business Studies, 37(4), 285-320. http://dx.doi.org/10.1057/palgrave.jibs.8400202

Mamman, A., \& Adeoye, B. (2007). Performance management in multinational companies in Africa: Implications for transferability of human resource management innovation to developing countries. Management in Development working paper series, Paper No. 17, Institute for Development Policy and Management, University of Manchester. May 2007, pp. 1-32.

McCrae, R.R., Terraciano, A., Realo, A., \& Allik, J. (2008). Interpreting GLOBE societal practices scales. Journal of Cross-Cultural Psychology, 39(6), pp. 805-810. http:// dx.doi.org/10.1177/0022022108323806

Mendonca, M., \& Kanungo, R.N. (1994). Managing human resources: The issue of culture fit. Journal of Management Inquiry, 3(2), 189-205. http://dx.doi. org/10.1177/105649269432010

Morris, T., \& Pavett, C.M. (1992). Management style and productivity in two cultures. Journal of International Business Studies, 23(1), 169-179. http://dx.doi. org/10.1057/palgrave.jibs.8490264

National Development Plan (2002-2008). Effective management for sustainable economic growth and poverty reduction. Kenya Government Press.

Ng, S.I., Lee, J.A., \& Soutar, G.N. (2007). Are Hofstede's and Schwartz's value frameworks congruent? International Marketing Review, 24(2), 164-180. http:// dx.doi.org/10.1108/02651330710741802

Nyambegera, S.M., Daniels, K., \& Sparrow, P. (2001). Why fit doesn't always matter: The impact of HRM and cultural fit on job involvement of Kenyan employees. Applied Psychology: An InternationalReview, 51(1), 109-140. http://dx.doi. Applied Psychology: An Internat
org/10.1111/1464-0597.00050

Peterson, M.F., \& Castro, S.L. (2006). Measurement metrics at aggregate levels of analysis: Implications for organization culture research and the GLOBE project. The Leadership Quarterly, 17, 506-521. http://dx.doi.org/10.1016/j. project. The Leader

Richardson, R., \& Thompson, M. (1999). The impact of people management practices on business performance: A literature review. London: IPD.

Rogers, E.W., \& Wright, P.M. (1998). Measuring organizational performance in strategic human resource management: problems, prospects, and performance information markets. Human Resource Management Review, 8(3), 311-331. http://dx.doi.org/10.1016/S1053-4822(98)90007-9

Ryan, R.M., \& Deci, E.L. (2000). Self-determination theory and the facilitation of intrinsicmotivation, social development, and well-being. American Psychologist, 55(1), 68-78. http://dx.doi.org/10.1037/0003-066X.55.1.68, PMid:11392867

Schwartz, S.H. (1994). Beyond Individualism-Collectivism: New cultural dimensions ofvalues. In U. Kim, H.C. Triandis, C. Kagitcibasi, S.C. Choi, \& G. Yoon (Eds.) Individualismand Collectivism: Theory, method, and applications (pp. 85-122) Thousand Oaks, California: Sage.

Smith, P.B. (2006). When elephants fight, the grass gets trampled: The GLOBE and Hofstede projects. Journal of International Business Studies, 37, 915-921. http:// dx.doi.org/10.1057/palgrave.jibs.8400235

Sundaram, A.K. \& Black, J.S. (1992). The environment and internal organization of multinational enterprises, Academy of Management Review, 17, 267-299. http:// dx.doi.org/10.2307/258806

World Bank, KIPPRA, CSAE, Oxford. (2004). Enhancing the competitiveness of Kenya's manufacturing sector: The role of the investment climate. Africa Private Sector Group, Investment Climate Assessment, Kenya, November, pp. 1-88.

Wright, P.M., McMahan, G., \& McWilliams, A. (1994). Human resources and sustained competitive advantage: a resource-based perspective. International sustainal of Human Resource Management, 5(2), 301-326. http://dx.doi. Journal of Human Resource $M$
org/10.1080/09585199400000020

Youndt, M.A., Snell, S.A., Dean, J.W., \& Lepak, D.P. (1996). Human resource management: manufacturing strategy and firm performance. Academy of Management Journal, 39(4), 836-866. http://dx.doi.org/10.2307/256714

Van de Vliert, E. (2006). Autocratic leadership around the globe: Do climate and wealth drive leadership culture? Journal of Cross-Cultural Psychology, 37, 42-59. http://dx.doi.org/10.1177/0022022105282294 